\title{
John Locke's Political Philosophy and It's Relevance to the Sustenance of Peace and Good Governance in Nigeria
}

\author{
Jibrin Ubale Yahaya, $\mathrm{PhD}$ \\ Department of Political Science, National Open University of Nigeria (NOUN)
}

\begin{abstract}
Philosophers are the mirror of the society where they use their glass to critically view and analyses certain human problems in order to propose a certain solution to that problem. The political philosophy of John Locke on the sustenance of peace and the conduct of good governance have given direction to any true democratic leaders who are in power to serve humanity and making lives better for his peoples. This paper was of the opinion that leaders in Nigeria since the return to democracy in 1999 in to the country the system has fail to meets the desired dividend for peaceful society and provision of functional government; this led to emerging problems of insecurity and pockets of conflicts in different parts of the country. This paper has uses secondary data source through reviewing relevant secondary information on the subject matter. This paper was of views that if leaders in Nigeria would be serious on the process of operating good governance they should provide an enabling environment that would promote peace and security among the citizens by ensuring welfare and the need of the peoples are the priority agenda that can drive the nation out of these menace of insecurity and conflicts through respecting rule of law, fighting corruption, separation of power and tolerance.
\end{abstract}

Keywords: Peace, Good Governance. Philosophy and Human needs.

DOI: $10.7176 / \mathrm{PPAR} / 10-5-06$

Publication date:May $31^{\text {st }} 2020$

\section{Introduction}

John Locke was in many ways unlike his predecessors, he was a multifaceted individual at one time a doctor, economist, university teacher and other times a politician and public administrator. Again, unlike those before him, he preferred to be outgoing rather than being contemplative; spending much time reading and mediating on same. For him, true knowledge in life could be found by getting involved in what is going on in one's environment not in reading books and restricting oneself to a particular sphere. As argued, one learns nothing when he is cut off from experience and experience is the only avenue through which one can learn anything.

John Locke (1632-1704) is among the most influential political philosophers of the modern period. In the Two Treatises of Government, he defended the claim that men are by nature free and equal against claims that God had made all people naturally subject to a monarch. He argued that people have rights, such as the right to life, liberty, and property that have a foundation of independent of the laws of any particular society. Locke used the claim that men are naturally free and equal as part of the justification for understanding legitimate political government as the result of a social contract where people in the state of nature conditionally transfer some of their rights to the government in order to better ensure the stable, comfortable enjoyment of their lives, liberty, and property. Since governments exist by the consent of the people in order to protect the rights of the people and promote the public good, governments that fail to do so can be resisted and replaced with new governments. Locke is thus also important for his defense of the right of revolution. Locke also defends the principle of majority rule and the separation of legislative and executive powers. In the Letter Concerning Toleration, Locke denied that coercion should be used to bring people to (what the ruler believes is) the true religion and also denied that churches should have any coercive power over their members. Locke elaborated on these themes in his later political writings, such as the Second Letter on Toleration and Third

\section{Research Questions}

The paper has following questions to ask:

i. What are the rationales behind John Locke political philosophy in relation to operation of good governance?

ii. How does Political Philosophy of John Locke would promote peace and good governance in Nigeria?

\section{Research Objectives}

The paper has the general objectives of investigating the political philosophy of John Locke towards promoting peace and good governance in Nigeria, with the following specific objectives:

i. To examine the rationales behind John Locke political philosophy in relation to operation of good governance

ii. To find out the relevance of John Locke Political Philosophy on the sustenance of peace and good governance in Nigeria. 


\section{Research Methodology}

The paper has uses secondary source of information through reviewing relevant various literatures on the subject matter to analyze how philosophical ideologies of scholars would fit with some contemporary issues of Peace and Good Governance in Nigeria.

\section{Definition of Terms}

\section{Letter on Tolerance}

Locke argued this point lucidly in his essay concerning 'understanding' that man was born knowing nothing and what they end up acquiring as knowledge, learn through observation and reflection experienced through the study of nature and reason with the aid of science and logic. As such, we can reduce our ignorance and improve our understanding of the world we live in through learning. It is on the basis of this espousal of the root of knowledge that he is often referred to as the founder of the age of reason.

\section{Concept of Democracy}

The concept of Democracy has combined two Greek words, "demo", meaning people and "Kratein" meaning the rule. Thus, the original meaning of democracy was the "rule of (by) the people". At this time, Herodotus included among its specific features, "equality before the law and popular deliberations" (Akindele, 1987: 41).

Subsequent Greek thinkers like Plato and Aristotle did not look with favour upon democracy. While Plato's attitude was decidedly hostile to democratic ideas, Aristotle accepted the ideas with severe qualifications (Rejai, 1967: 2). This explains why ancient democracy did not presuppose equality of all individuals. In it, existed the prevalence of slavery and, a minority of the populace had no political rights. Athens, the greatest of the city democracies, limited its franchise to the native-born citizens (Funk and Wagnalls).

Greek discussion of democracy was followed by Rome's contribution to democratic ideas and government in antiquity. The hallmark of this contribution was Rome's development of the "idea of constitutionalism" and her emphasis on laws as the system of norms binding on both the "rulers" and "ruled".

However, the civilization of antiquity collapsed after a while. This collapse, and the then increasing predominance of religion over all aspects of life led to the evolution of medieval democratic ideas. More interestingly, the existence of the Christian religion, which emphasized the rights of the underprivileged and equality of all men before God contributed to the development of democratic ideas in the medieval period. In addition, most of the Christian ideas stressed the notion of a "moral law of nature", and the quest for a universal society.

After the renaissance era came the 17th and 18th centuries when John Locke and Jean Jacques Rousseau in addition to Thomas Hobbes popularized the concept of the "Social Contract which may be said to be the most rational of all the theories about the democratic origin of states and civil government (Khan, 1972: 27;).

Even though, many obstacles riddled the historical stages of democratic ideas, it gained ground in the nineteenth century when "every important Western European monarch started to adopt a constitution limiting the power of the crown and giving a considerable share of power to its people" (Funk and Wagnalls, 1984). This period witnessed the various elaborations of democratic theory by people like Abraham Lincoln, Thomas Jefferson, John Stuart Mill and Alex de Tocqueville. In short, the historical background of democratic ideas as outlined up to this point is

The Hobbes and Rousseau, John Locke also theorized about the concept of social contract. However, unlike Rousseau's views of the individual's in capabilities, John Locke believed that life in the state of nature was pleasant, but men were hampered by the absence of any socially recognized authority to adjudicate and settle disputes and conflicts between them hence the need for democratic government

As for John Stuart Mill, he believed in the welfare of the individual, as well as individual liberties. Writing on Democracy and liberty, he maintained that the only way power can be, or, should be exercised over any member in the society against his will, is when it can be established that, such individual intends to injure, or, do harm to other (Rejai, 1967). He further emphasized the notion of liberty within the framework of representative government. Along this analyticalplane, argued, Awa (Akindele, 1993; Akindele et al., 1998), Schumpeter (1955) defines democracy as:

"the institutional arrangement for arriving at political decision, in which individuals acquire the power to decide by means of a competitive struggle for the people's vote."

Due to the nature of their reasoning, Rousseau and other theorists (e.g. Lincoln) mainly concerned with the welfare of the community as a whole, are classified into the "collectivistic school of thought", while John Locke and John Stuart Mill are classified into the "individualistic school" relative to the emergence of democratic system of government which emphasizes equality and liberty of men.

According to Nzongola-Ntalaja (2001) "democracy is a universal form of rule" which, even though, "may have variable manifestations in different historical and social settings", have such manifestations tied together by a common thread". Democracy in this sense, according to him, refers to "three basic ideas": 
Democracy as a moral imperative, in the sense that it represents a permanent aspiration of human beings for freedom, for better social and political order, one that is more human and more or less egalitarian.

Democracy as a social process, in that it is a continuous process of promoting equal access to fundamental human rights and civil liberties for all and. In other word Democracy as political practice or a mode of governance based on the principles of popular sovereignty, the rule of law, accountability, participation and alternance (meaning leadership renewal or change)

In his contemporary contribution to the concept of democracy, Olowu (1995:16) opined that "democratic arrangement constitutes an approach to connecting the "rule-ruler -ruled relationship" which forms the core of governance. This probably explains his definition of democracy as:

"'a system of governance that underscores the plural nature of politics and hence gives

recognition to the diversity of social forces in any political community"

On the same token, Sartori (1987:34) had earlier claimed that:

"Democracy exists when the relation between the governed and the government

abides by the principles that state is at the service of the citizens and not the citizens

at the service of the state; that the government exists for the people and not vice-versa."

Looking at all above statement of scholars on the meaning of "Democracy " which means a government is just like a social contract where group of people agree to rent a power to an one elected or individual by will and consent of all to take care of the general needs of the group as a society no one can live in isolation rather must live in group and a group need a certain figure that can speak and act on behave of the peoples.

\section{Concept of Governance}

The concept of governance was real connection with "economic, political and social aspects of a Nation" (Shehu, 1999), has not been amenable to easy or simplistic definition. In other words, the concept has not been an exception to the volatility and eclecticism for which the disciplines in the Social Sciences have been globally noted whenever it comes to the conceptualization of core issues.

This explains Esman's (1997: 1) claim that "no two political scientists would agree on what the concept of governance is, or what it means". In fact, as Hyden (1999) once noted, "only few authors (have) define(d) it (the concept of governance) with a view to serving analytical purpose" hence, "governance as a concept has not been extensively used (or defined) in the political literature until very recently when it gained currency" (Nkom and Sorkaa, 1996).

This notwithstanding, as Hyden (1999: 24) once argued, "the concept of governance has come to occupy a more prominent position in the discourse of international development". If this is correct or, should be taken to be correct, the question needs to be asked that: what exactly or actually is governance?

World Bank (1989) defines governance as "the manner in which power is exercised in the management of a country's economic and social resources for development". According to the World Bank (1993), governance has three dimensions. These dimensions which, Eyinla (1998), equally noted are: "the nature of politicalregimes; the exercise of authority in the management of social and economic resources and, the capacity of government to design and implement policy and to discharge its functions".

These dimensions were specifically identified and concretely elucidated by Olowu and Erero (1997) who both conceptualized governance as relating to the "rule-ruler-ruled relationship". Specifically, Olowu and Erero (Ibid) identified the three dimensions of governance in the context of "rule-ruler-ruled relationship" as inclusive of "functionalism, "structuralism" and "normativism". According to them, functionally, governance deals with "rule-making, legitimization, and enforcement" while it structurally comprises of three distinct institutions: the "ruler or the state", the "ruled or the society" and, the "rule of law". In this regard, Olowu and Erero (ibid) viewed governance as the "relationship between state and society institutions". In the same vein, they claimed that "normatively, this relationship highlights the values associated with good governance". These values according to them include: "transparency, organizational effectiveness, accountability, predictability, legitimacy, popular participation and plurality of policy choices".

Within the same context, Boeninger (1992), defines governance as the 'good government of society". According to this scholar, governance has three dimensions: political, technical and institutional. Nkom and Sorkaa (1996) synopsized the interrelatedness of these dimensions thus:

The political revolves around the commitment to exercise authority or public control in a just, legitimate and rule-oriented fashion. The technical concerns issues of efficiency, competence or the capacity to manage public affairs effectively to solve problems, and to produce good results in resource mobilization and public management. The institutional involves options, choices and growth - enhancing activities by the public while ensuring honest or good conduct on the part of the public officials.

In the same vein, Landell-Mills and Serageldin (1992) argued that governance encompasses two interrelated dimensions: political and technical both of which consist of the government's "will to govern well and the capacity to efficientlyand competently handle public management". Governance, according to Gould (1972) refers to the 
act of exercising control over others, inducing others to behave in specified ways as required by law. It is "policy making and policy execution regulated by systems of law and guidelines which are segregated into specific operations to achieve specific national objectives (Shehu, 1999: 1). To Brautigam (1991) and Ikpeze (1999:73), governance connotes "the exercise of power and authority in both political and economic spheres". Thus, as Ejituwu (1997), argued, "governance implies the exercise of power by a person or group of persons for the benefit of the populace" because, as he equally later claimed, it is through governance, that "the government in power dictates the form of relationship it establishes between it and the people as well as the goal of the state in economic, political and social terms" (Ibid)

Implicit in the foregoing conceptual analysis of governance is the fact that, the latter connotes "the use of political authority and exercise of control over a society and the management of resources" (Wai, 1995). Hence, according to Obadan (1998: 24), governance - (in this sense)- includes:

Institutional and structural arrangements, decision-making processes, policy

formulation, implementation, capacity development of personnel, information flows, and the nature and style of leadership within a political system.

Jega (1999: 101) analyzed the concept of governance in relations to the "person entrusted with political power and authority". In this regard, governance according to him, involves the following:

$>$ responsibility and responsiveness in leadership and in public service;

$>$ accountability in the mobilization as well as in the utilization of resources;

$>$ discipline, effectiveness and efficiency in handling public (as well as personal) affairs;

$>$ Selflessness and impartial service to the people; and

$>$ Popular participation and empowerment of the people in the conduct and management of their common affairs (Ibid).

For governance as the "duty of government to see to the orderly and stable management of the economy" (Ukpong, 1999), to have the foregoing attributes and, be effective, efficient and beneficial for democratic political arrangement, it has to be good. This is more so, since we can, as well, have bad governance.

The possibility of bad governance could be said to be what the World Bank had in mind in 1989, when it began to dichotomize between good and bad governance by "advocating a political reform approach to government as a way of ensuring positive economic growth” (World Bank, 1989; Idowu, 1998).In fact, the World Bank (1992) identified the features of bad governance as follows:

- Failure to make a clear separation between what is public and what is private, hence a tendency to divert public resources for private gain;

- Failure to establish a predictable framework for law and government behavior in a manner that is conducive to development, or arbitrariness in the application of rules and laws;

- Excessive rules, regulations, licensing requirements, etc, which impede the functioning of markets and encourage rent-seeking;

- Priorities that are inconsistent with development, thus, resulting in a misallocation of resources;

- Excessively narrow base for, non-transparence, or, decision-making.

This explains Obadan's (1998: 25) characterization of bad governance as a system dominated by "ugly problems like pervasive corruption, lack of public accountability and "capture" of public services by the elites among others".

As we understand the concept of Democracy, we need to further explain the concept of good governance at this point.

As cited by Ogunba (1997: 1), once noted "the way apeople are governed is of paramount importance in determining the quality of life of the people". It is equally more so, if as Esman (1997: 1), opined, "governance is a process that requires a viable authority" through which "the leaders are expected to exercise the power that resides with them in the interest of the state" (Ejituwu, 1997).

The need for good governance is not farfetched looking at the fact that:

If governance is arbitrary, oppressive and capricious, the collective psyche of a people can be damaged and individuals within the community can suffer various forms of disorientation. If, on the other hand, governance is open, democratic and humanistic, a people can experience a sense of rejuvenation and fulfillment, which can lead to highly positive achievements (Ogunba, 1997).

This explains Obadan's (1998: 39) position that, "it is the responsibility of citizens to demand good governance" because "it (i.e., good governance) may not be forthcoming from the political leaders without prodding". Commenting on good governance, Esman (1997: 1) argued thus:

Before governance can be considered good, government has got to be effective. It must first command the respect and allegiance of the people over whom it exercises governance and, must satisfy certain basic collective needs.

He went further to identify some minimal elements and/or essentials of effective (good) governance as 
inclusive of: "provision of security for the people", "defense of the territorial borders of the state", "protection of lives and property", "enforcement of laws to enhance predictability" and, "economic development". According to this scholar, "governance requires the ability to ensure the wherewithal of sustained government". He equally asserted that "effective (good) governance requires that public authority be able to raise the revenues necessary to pay for services that must be provided". The essence of this argument is that, "effective governance must be able to make possible the performance by the state of certain basic services" - transportation, communication, education and health services - "relatively cheaply and reliably" (Erero, 1996). This is more so, since effective governance Means the capacity of the state - through its power of determinism or, authoritative allocation of scarce critical societal resources - to deliver the basic necessities of life to the governed and, equally "facilitate the process of economic development".

These lines of argument tally with those of Obadan (1998: 25) and Amoako (1997: 10), who have posited that: Good governance implies efficient and effective public administration, good policies and sound management of natural resources. It calls for the ability of a state to anticipate challenges to its wellbeing, provide core services with people and then argument these services, act as a catalyst of change, and guide the various forces in a society toward harmony (and national development) devoid of ideological imperialism and multi-dimensional genocidal tendencies) (Emphasis mine). Pursuing the same line of argument, Obadan (1998) further claimed that:

Good governance implies ruling on the basis of equity and social justice, and an end to corruption, nepotism and political manipulation of public institutions. Only when citizens have the belief that their government operates on their behalf, in an open and accountable manner, will government be able to obtain their willing co-operation in, for example, mobilizing resources for development.

Driving home this line of argument, Obadan (Ibid: 34), emphasized that, through good governance, a government should be able to effectively perform, among others, the following tasks:

- Establishing a foundation of law;

- Maintaining a non-distortionary policy environment, including macro-economic stability;

- Investing in basic social services, infra-structure,

- Protecting the vulnerable group in the society; and

- Protecting the environment.

Other scholars have considered good governance vis-à-vis the raison d'etre of statehood in this manner as well (Kaufman, et al., 1999; Corkery and Bossuyt, 1990; Healey and Robinson, 1992, 1994; Bello- Imam, 1997; Ayoand Awotokun, 1996, 1997; Nkom and Sorkaa, 1996; World Bank, 1989, 1992, 1993). These scholars' works on the concept of good governance treat it as a system of rulership that is devoid of political expediency and antidemocratic political ends. It is deducible from their works that, good governance stands for dignified existence of all political animals in democratic political settings within the global political community. According to Obadan (1998: 24) "good governance consists of five fundamental elements". He listed them thus:

- Accountability of government officials (political leaders and bureaucrats) for public funds and resources;

- Transparency in government procedures, processes, investment decisions, contracts and appointments. Transparency is a means of preventing corruption and enhancing economic efficiency;

- Predictability in government behavior. This is particularly critical to the carrying out of economic transactions between individuals and in taking investment decisions: governments and public institutions should not be capricious in their behaviour and actions;

- Openness in government transactions and a reliable flow of the information necessary for economic activity and development to take place. Without information, rules will not be known, accountability is low, and risks and uncertainties are many. With these the cost of committing capital is also huge. An open system should, thus, be encouraged to release information to stakeholders and promote dialogue among the people as well as ensure their active participation in the socio-economic development of the country.

- Observance of the rule of law must be adhered to by government and its citizens; this means that governments and institutions should be subject to rules and regulations, which are understood by everyone in the society (Ibid).

The foregoing put together, undeniably point to the fact that, there is a relational umbilical cord between governance and democracy. In other words, it points to the fact that, there exists a significant degree of affinity between the two. This is the subject matter of focus in the next section to which we now turn.

\section{Peace as a concept}

Peace is regarded "as the absence of war, fear, conflict, anxiety, suffering and violence and about peaceful coexistence" (Francis, 2006; Igbuzor, 2011). Although this definition has captured elements of peace, it was criticized by scholars like Ibeanu (2006) for lacking the adequate concept of peace. To overcome this limitation Ibeanu (2006) thus defined peace as a "process involving activities that are directly or indirectly linked to increasing development and reducing conflict, both within specific societies and in the wider international 
community". In this respect, peace therefore connotes the absence of violence or war, the presence of justice, equality and development; the existence of rule of law, respect for human life and dignity, and tolerance among and between people; maintenance of a balanced ecosphere and more importantly, having inner peace and wholeness. To add to this debate, Johan Galtung, a renowned Norwegian theorist provided three types of violence (direct, structural and cultural) to help understand the concept of peace across the globe.

Galtung (2011) consider direct violence as the physical, emotional and psychological aggression caused by a direct attack through fighting or war thereby resulting in to deaths, destruction of property, and displacements of citizens among other consequences. He sees structural violence as caused by an unjust structure not to be equated with an act of God which involves structures that cause human suffering and death which are quite avoidable if good governance exists. In his view cultural violence occurs as a result of the assumptions that bind one to structural violence. For instance, one may be indifferent toward the plight of the poor which create discrimination, injustice and suffering thereby leading to the absence of peace in the society. In addition, Galtung's positive and negative peace framework is the most widely used model by most scholars. While negative peace refers to the absence of direct violence, conflict and war at international, national, community and individual levels, positive peace refers to the absence of indirect and structural violence, inequality and injustice, unjust structures and policies and inner peace at individual levels. Due to its comprehensives, this conception becomes the most widely used by peace and conflict researchers.

As earlier provided Ibeanu (2006) has attempted to provide an understanding of peace which centers on increasing sustainable development and reducing conflict, both within societies and in the wider international community. He further pointed out that despite the general knowledge of peace; there are variations its meaning especially through the lenses of philosophy, sociology and politics. According to a philosopher, peace "is a natural, God-given state of human existence without the corruptive tendencies of man". According to sociologists, peace refers to a condition of social harmony in which there are no social antagonisms among people or group in a given community. For the political scientists, peace is a political condition that makes justice possible in any given society thereby entailing political order. Similarly, cultures and civilization have different viewpoints of peace. For instance, in a society that is constantly perpetuated with violence and armed conflict, it will view peace as the absence of war and violence. In a political community governed by unjust policies, it may interpret peace with the presence of freedom and justice. In a society that is materially deprived or in poverty situation, it may perceive peace as equality, development and have the basic needs of life. From whichever perspective, renowned scholars, practitioners and activist of peace have attributed different related meanings of peace into six:

1. Peace is the absence of war

2. Peace is the absence of direct violence

3. Peace is the absence of injustice

4. Peace is the absence of fear

5. Peace is the presence of respect and

6. Peace is the presence of tolerance

Although several conceptions and models of peace have been advanced in which peace research might prosper (Ibeanu, 2006; Francis, 2006; Galtung, 2011; Igbuzor, 2011), it should further be understood that peace is a natural social condition, and war is not. For peace scholars, students and advocates, such information is good enough for a rational group of decision makers to avoid conflict, violence or war. This is because, violence is considered morally sinful, and therefore non-violence which is virtuous should be cultivated in the society as advanced by a variety of religious traditions (Christianity; Hinduism, Buddhism, Islam, etc). Indeed, its importance lies in the fact that:

Peace is a sine qua non to development.

- It is being eroded by perennial conflicts.

> Their occurrence pervades virtually all spheres of the national life.

$>\quad$ The effects of the conflicts are many and multi-dimensional.

> Insecurity of lives and properties is one of the consequences of conflicts.

- Steps should be taken to control conflicts and ensure peace in society through preventive measures instead of reactive measures. (Ali,2018)

\section{Conflict as concept}

The definition of conflict like peace is also contentious. However, most scholars are of the opinion that conflict usually reflects a class of interest or goal between parties, which may be individuals or group of individuals, or ethnic groups or states. Conflict according to most scholars occurs "when two or more people engage in a struggle over values and claims to status, power and resources in which the aims of the opponents are to neutralize, injure or eliminate their rivals. He further explained that conflict emerges whenever one party perceives that one or more goals or purposes or means of achieving a good or preference is being threatened or hindered by the activities of one or more parties." Put together, in conflict parties perceive or treat each other as a stumbling block that results 
in frustrating the other in attaining a set of goals, or even furthering one's interest through their attitudes, behaviors or actions (Akpuru-Aja, 1997). Generally, the conflict has been considered an obstacle to progress, political stability, economic prosperity and overall socio-economic development of any society because of its destructive impact. This therefore means that conflict must be timely averted or managed properly as failure to do so will reflect a determined action or struggle over a goal, which may be overt or subtle; manifest or imaginary.

\section{Ethnic conflict:}

Nigeria is a country of many nations with hundreds of tribes and ethnic groupings. The relationships between for instance political parties in underdeveloped nations like Nigeria are likely to be more conflictual than those in advanced polities (Tyoden, 2016). Given the social differences in Nigeria, the quest for power mostly depends on the existing nature of the relationship between these sectoral groups. It is therefore no wonder that the visibility and relevance of the Afenifere, the Ohaneze N'digbo, the Arewa Consultative Forum, the Southern Leaders Forum, and the Ijaw National Congress etc- each is articulating its own agenda for the ethnic groups they belong instead of the overall development of the country (Abbas, 2016). Lending credence, Jega (2002) earlier assert that the major aspect of the most ethnic conflict in Nigeria is the contesting hegemonic power used in making members react negatively in given situation.

\section{Political conflicts:}

Since the amalgamation of Nigeria in 1914, most incidents of political conflicts have been associated with appointments, national population census, resource allocation and electoral processes leading to election rigging, vote buying, corruption, the use of political thugs and other electoral malpractices as well as unfair sharing of political gains. In the electoral process, according to Abbas (2013) from 1999 to date political violence has continued to assume an alarming dimension, including assassinations and abductions, inter and intra party conflicts, religious intolerance which created suspicion and acrimony leading to many communal and sectarian violence. As Onuoha (2003) further argues, those interested in retaining power or winning at all costs, and especially actors who were in control of the instrument of the state simply "fixed" the result of the elections they desired to win leading to protests. The reasons for such do or die politics is not farfetched from the fact, since the state is the major means of capital accumulation in Nigeria and considering the prevalence and ubiquity of poverty and dependence in the country, the struggle for the control of the state and its resources, take on a life-and-death struggle. Simply put, in Nigeria access to political power is seen as access to economic power.

\section{Economic Conflict:}

Looking at the Nigerian society and its environment, the quest for control and distribution of economic resources is majorly the basis for many conflicts among the citizenry with the relationship between parties taking cues from this basic consideration. It is in this similar view that liberal structural theorists such as Galtung see conflict as a phenomenon that is built in human societies according to how they are structured and organised. That is to say conflict emanates as a result of deep-rooted structural dysfunction which looks in to problems such as the inequality in the distribution of income, endemic corruption, injustice, poverty, illiteracy, high unemployment rate, hunger, disease, inflation, exploitation and tax havens on citizens, high rates of crimes, overpopulation and general economic underdevelopment. Galtung (2011) argues that whenever economic and political discrimination and lack of tolerance in plural societies are embedded in human relationships, conflicts are bound to occur higher than the societies where opposite socio economic relationships are established. All political economist there by start by asking a common but a general question as to what are the reasons for poverty, hunger and the general underdevelopment of Nigeria despite all its abundant natural and human endowments? As it can be observed, these system's dysfunctions involve deliberate policies and structures that cause human suffering and death which are quite avoidable if good governance exists in the society.

\section{Social Contract Theory of John Locke's}

John Locke's Social Contract Theory over the years has come under several criticisms. Those who criticize his Social Contract Theory assert that his ideas are incoherent, hypothetical, unrealistic and ahistorical in nature (Laslett, 2013; Tate, 1965). However, there are those who also argue that the principles of Locke's Social Contract Theory are synonymous with the principles of democracy and as a result that provides useful framework for analyzing and understanding the practice of governance (Ritchie, 1891; Lloyd, 1901; Ellis, 2006; Hicky, 2011; Hampton, 1980; Abbott, 2008; Gherghe, 2011). That is why Ward (2005) concludes that John Locke was the harbinger of democracy. Elsewhere Laslett, (2013) and Tate (1965) confess that despite the several criticisms and deficiencies associated with social contract generally, scholars have not stopped using it as a model of analysis in different areas of research. This shows that irrespective of the tag of absoluteness attached to Social Contract Theory by its critics it has not lost its allurement in research and political behavior.

The observation of Laslett, (2013) and Tate (1965) elucidates why the social contract is still being used as a 
model of analysis. On a general note, for instance, social contract has been used at different times as a tool of analysis in such areas as medicine (Reid, 2011); agriculture (Cotlear, 2006); family (Sepinwall, 1999, Paz-fuch, 2011); business and marketing (Vaaland, Heide \&Grohaug, 2008; Judith, 1993; Yang, 2000); Millennium Development Goals (Hickey, 2011). Other areas where Social Contract Theory has been applied include Workers' Union relationship and their employer (Judith, 1993; Yang, 2000); religion, (Novak, 2005) international relations and diplomacy (Paz-Fuchs, 2011) and marriage (Shapirio, 2009).

That notwithstanding, these contributors to Social Contract Theory have not been able to investigate why several democracies in African countries like Nigeria has not been faring well in line with the expectations of the principles of democracy. Elisabeth Ellis rightly noted that contributors have not been able to provide a satisfactory response to two persistent complaints about social contract theory's application to imperfect political conditions. First, how can political authority derive from contract theory? How can authorities' consent be granted by real world citizens? This point to the fact that Social Contract Theory needs to be applied to investigate why some democracies like Nigeria is in the situation in which it is. One of the reasons explanations for the imperfect conditions of democracy are not found is the absence of studies on Social Contract Theory and democracy (Ellis, 2006).

Since there are limited critical applications of Social Contract Theory to the practice of democracy, many scholars like Laslatte (2013); Tate (1965); Gauthier (1977), Hegel (1988) and Hume (2006) are very fast to dismiss the Social Contract Theory as a mere academic fiction. But scholarship needs to move beyond those criticisms to attempting to apply the Social Contract Theory to specific cases of democratic practicing nations in other to see how the imperfect democratic situations can be explained and understood from a theoretical and philosophical perspective. Once this is done, it will address the lacuna in the literature on John Locke's Social Contract Theory and the practice of democracy, which otherwise gives the impression that John Locke's Social Contract Theory is not useful. It is for this reason, that this study considers Nigeria democratic practice as a case study for the application of John Locke's Social Contract Theory in order to understand the nature and character of the practicing of democracy in Nigeria.

Political philosophy is a discipline which does not treat issues apart from the realities of human experience. Political philosophy makes meaning when it is applied within the context of a societal setting. That is why political thinkers take into consideration the political, cultural, economic, historical and religious factors surrounding man's life. Since man is political, and political thought has to do with collective decision making, political philosophy puts into account issues regarding the origin, nature and development of human societies. John Locke's Social Contract Theory is an attempt to establish the theoretical base for the establishment of an ideal civil society and government which will promote the security, liberty and wellbeing of the people who so form the society and government (Gherhhe, 2011).

In the Two Treatises of Government Locke theorizes how to establish an effective social contract system in the society; how to determine when the social contract is violated or abused; how to protect the social contract system and the best way to handle abuses of social contract agreement by leaders. Locke's Social Contract Theory as enunciated in the Two Treatises of Government was to challenge the abnormal political situation in 17th and 18th Century England, at the same time to direct the political pathway for the future (Dienstag 1996).

Social Contract Theory is associated with three major modern philosophers; Thomas Hobbes, John Locke and Jean-Jacques Rousseau (Gauthier, 1977; Tienda, 2002). These were great political philosophers who came up with great ideas that laid the foundation for the theory and practice of democracy today. These theorists agree that the formation of the state and civil governance is the product of a compact of the people. The implication is that, the state and its leadership cannot be in place if the people do not collectively consent to establish them (Faber, 2011). Social Contract Theory sets in motion the picture of an ideal state whereby the authority of the state and its leaders is legitimized by the consent of the people. It provides the principle which explains human relations and existence.

For example, in 1707 the Kingdom of England and Scotland accepted to enter into a compact to be amalgamated. The thirteen colonies in America agreed to come together to form the United States of America and to establish its government therein in 1776; similarly, in 1867 some British colonies in North America agreed to come together to form a Confederation known today as Canada (Lloyd, 1901; Dare, 2003). In 1963 Sabah and Sarawak agreed to join the Federation of Malaysia (Means, 1963; Kahin, 1964 and Fong, 2011). This to some extent illustrates the relationship between Social Contract Theory and the emergence of nation-states.

John Locke's Social Contract Theory is a constitutional contract that is aimed at protecting the people's life, liberty and property. (Locke, 2014). In Locke's perspective: the powers of the government are not absolute but defined by the constitution and the people who equally reserve the rights to check the government. The people hand over their rights to protect, judge and fight for themselves to a constituted authority but reserve the right to remove erring leaders.

Locke's social contract is synonymous with Liberal democracy because his principles of Social Contract Theory provided the inspiration for constitutional democracy and the idea of fundamental human rights protection 
(Shapiro, 2003; Popkin \& Stroll 1996). This is in line with the principles of liberal democracy and the UN Universal Declaration of Human Rights (UDHR) promulgated in Paris in 1948 by the UN General Assembly Resolution Number 217 (A) (III) as best practices by nations of the world. To effectively protect the people's rights, Locke specifies some principles the government should put into practice. Locke's ideas eventually gave birth to liberal and representative democracy, one of the fastest growing and popular systems of government today (Hampton 1986; Baumgold, 2005; Popescus, 2012).

The last decades have witnessed an unprecedented wave of democratization around the world (Cervellati, Fortunato \&Sunde, 2014; Thompson, 2010). In fact, there are about 200 countries in the world today practicing different forms of democracy. Others are undergoing the process of being democratized, some fully democratized while others are partially democratized (Karatnycky, 2002). The system of democracy postulates human freedom and equality. It is for this reason that Omelle states that whatever deficiencies there are in the Liberal democracy it must be credited for the great avenue it provides for individual and group for self-actualization. Democracy should be affirmed without fear of contradiction; that of all forms of governance ever devised by man, democracy is seen by many as the best form of government. Democracy today is the most cherished system of government across the globe. So, over the years there has been increased demand and incorporation of countries into the practice of democracy (Karatnycky, 2002; Omelle, 2005).

Democracy is particularly appealing to the oppressed peoples of the world whose yearning for freedom, equality and justice are being frustrated daily (Nnoli, 2012). In most of the countries practicing democracy, there exists one form of problem or the other. Even among mature democracies. In the USA for instance, there is still racial discrimination between the blacks and the whites. A case of electoral malpractice was even reported in Florida in 2000. This is succinctly captured by Pippa Norris who says that:

Even long-established democracies are not immune, as exemplified by the notorious hanging chards in Florida in 2000, more recent accusations of voter suppression through over-zealous identification requirements during the Obama-Romney contest, and security vulnerabilities in UK postal ballots (Norris, 2012:2).

Africa is not spared from the crisis which confronts democracy. The wave of democratization which came to African countries at the dawn of decolonization evaporated by 1965 due to political violence and general insecurity (Elaigwu, 2011). African democracies are associated with a considerable number of violent crises from Liberia to Nigeria, from Sierra-Leone to Angola, from Ivory Coast to Algeria. Ethnoreligious and political formations were up in arms against one another in democratic states that describe themselves as democracies. As a result, these African countries do not enjoy relative political tranquility which democracy is purported to provide (Adebanwi, 2004).

Democratic governments all over the world today are undergoing one problem or the other. An assessment of the freedom of the world's political rights and civil liberties indicators over the past five years shows the most pronounced declines in sub-Saharan African countries (Puddington, 2014). The growth of such negative trends undermines democracy and the principles of Social Contract Theory among people. The widespread use of violence in democratic states is generally regarded as a sign of the failure of the democratic process. The breakdown of the democratic order may reflect policy failure of the regime policy-makers or minorities to undermine democratic values. But democracies that are able to avoid such disorder while still being competitive and free and a better performer than those that are dominated by violence or those that restrict freedom in the name of order (Powell, 1992).

Besides this, electoral malpractices and political violence are the order of the day in some countries like Egypt. Egypt's failed attempt to conduct elections in 2011 and 2012 during President Mohamad Morsi threw the country into chaos with widespread protests from millions of Egyptians who thronged the streets of the country in the spirit that they were denied the opportunity to collectively decide who should lead them; this attitude of the Egyptians was a show of the spirit and desire to be involved in the choice of their leaders through a process which involves social contract principles. What happened in Egypt illustrates that leadership devoid of the people's consent breeds uproar. The major problem was not that the elections failed, but because there was no social compact in the country on how to transform to a democratic regime via a laid down code for the elections (Brown, 2013).

The commonest problem of democracy in Africa is the quest of leaders to remain in power for life against the will of the people. There are many cases in Africa regarding their leaders who want to be in power for life. They have used cruel means to push their agenda. In Zimbabwe, for instance, President Robert Mugabe who has personal control of the Armed Forces in the country has used it to brutally deal with the citizens to quell opposition. He has repeatedly violated human rights and promoted massive electoral fraud which has brought about civil unrest in the country (Mangongera, 2014). Robert Mugabe perpetuated these crimes so as to be the Life President of the country. Mugabe's leadership ambition made him violate human rights thus undermining liberal democratic practice. Recently in July 2015 the two terms President of Burundi, Pierre Nkurunziza amended the constitution of the country to contest the Presidential Elections for the third time contrary to the provisions of the Constitution of 
Burundi. This attitude is incongruous to rule of law and to the principles of social contract.

Nigeria is not an exception. Nigeria shares the same fate with those nations that do not adhere to the principles of Social Contract Theory in their practice of democracy. Since Nigeria was founded in 1914, it has more or less been in perennial transition from one form of governance to another; some of the transitions were democratic and others were not (Diamond, Krirk-Greene and Oyedirin, 1997). Both the democratic and military regimes in Nigeria have saddled the people with oppressive administrations which violated fundamental human rights and have at different moments failed to guarantee peace and security.

According to Elaigwu (2011), there were several indicators which pointed to the fact that Nigerian democratic experience in the First Republic (1960 to 1966) was not going well. These indicators were: breakdown of rules and regulations of party politics, abuse of political power, misappropriation of public funds and widespread corruption among public servants. Other indecent were human rights violation and insecurity, disenfranchisement, electoral malpractices, political violence and ethnic politics. All these led to the collapse of the First Republic. The widespread political violence which erupted in various parts of the country resulted in the first military coup of 15th January 1966. This was the beginning of the military rule in Nigeria. In 1984 and 1993 when Nigeria had the opportunities to move on to a presidential democracy the military intervened again and interrupted the process (Elaigwu, 2011).

Nigeria's democracy has experienced numerous crises and conflicts since 1960. These conflicts signaled a breakdown of law and order, peace and security in the country. These crises include the highly controversial and rigged Federal Election of 1964; the Action Group Crisis of 1962, the Western Election Crisis of 1965, the Electoral Crisis of 1979 and 1983. These crises denied the people the opportunity to legally choose their leaders in the country. Consequently, the unity of the country has been threatened since then. The crises in the First Republic (1964-1966) led to the 1966 coup in which the Prime Minister Alhaji Tafawa Balewa and Sir Ahmadu Bello, the Sultan of Sokoto were assassinated. These episodes led to the Nigerian civil war which lasted three years (1967 to 1970) resulting in the death of about two million people (Nwosu, 2008). Over the years it has been very hard to describe Nigeria as a strong nation state that upholds the social contract principles due to the constant ethnic rivalry that has permeated every facet of Nigeria's life.

From 2003 to 2015 Nigeria witnessed increased insecurity of human lives and property, violation of human rights, increased crime rates; the emergence and spread of politically motivated violence and assassinations; increased importation of illegal ammunition; an upsurge in ethnic, communal and religious conflicts; proliferation of ethnic and sectional militias (Tyoden, 2005; Okau, 2011). Admittedly, in 2007, the President of Nigeria, Alhaji Umaru Musa Yar'Adua accepted that the 2007 General Election process through which he became President was flawed. There are several cases of unlawful impeachments of those whom the people elected to represent them, abuse of power, tyranny, protests against the Nigerian statehood among other issues (Egwemi, 2010). Several attempts have been made to study and proffer solutions to the problems associated with Nigeria's democracy. Despite these efforts, the problems confronting Nigeria's democracy seem to prevail. The literature available shows that none of the studies conducted on the problems of Nigeria's democracy have applied the Social Contract Theory of John Locke to look at the democratic situation in Nigeria from a theoretical perspective. The purpose of this study is to adopt a new approach to understanding the real factors responsible for the crisis being experienced in Nigeria's democracy. For this reason, the Social Contract Theory of John Locke is used as a framework to understand the nature and character of Nigeria's democracy in other to find out if the problems beseeching the practice of democracy are related to the dichotomy between John Locke's Social Contract theory and the practice of democracy.

\section{The Impact of John Locke's Political Theory:}

John Locke's influence went beyond his own time and country in various ways. Scholars after him borrowed his ideas in arriving at their own thesis about liberal democracy and bourgeois economic arrangements. For example, Montesquieu, in his spirit of the laws, agrees with Locke that separation of powers offered the best hope of avoiding tyrannical government. Both envisioned the legislative and executive organs keeping an eye on one another.

Locke was equally significant because he was first and foremost a reasonable man who believed in the rationality of men. Many of his ideas were reasonable and most of his philosophies arose during upheavals. He was reasonable to the extent that his ideas were not challenged for centuries. Meaning that Locke's political views provided profound and persuasive formulation of civic culture; it was the most influential in the $18^{\text {th }}$ century and his views were in the mainstream of English political developments leading to constitutional developments.

Locke insisted that the authority of the government must be based on the consent of the people; that the powers of the monarch are limited; that the main object of the government is to help the people not to ruin them; and that the government must be resisted if it steps beyond its bounds that is, its proper authority or overlooks the common good. With this outlook and political world view, Locke succeeded in capturing the minds and hearts of those who were foremost in the building of modern European society and state in a way greater than his contemporaries. His idea emerged as the most relevant in the foundation of a liberal and constitutional state. His 
political theory found full culmination in the French and American bourgeois revolution especially the right to resist. As Sabine (1973) puts it, his sincerity, his profound moral conviction, his genuine belief in liberty, in human rights and in the dignity of human nature united with his moderation and good sense, made him the ideal spokesman of a middle-class revolution.

\section{Features of John Locke's Idea on Liberal Democracy:}

- Consent: the real hallmark and interests of the individual is considered in the organization of the state as elucidated by Locke.

- Constitutionalism: this according to Locke entails putting in process a document that regulates the conduct of individuals in the society based on consent of all and sundry.

- Tolerance: the ability of the system entrenched to accommodate even conflicting opinions in the society.

- Individual liberty: this entails the dignity and worth of the human person and the freedom accorded in all perspectives.

- $\quad$ Stability: this according to Locke must come to bear as only a stable system can ensure individual liberty and effective governance.

- Ownership of properties: Locke's idea on liberty and liberal democracy emphasizes the existence of the actualization of self-worth even in terms of individual ownership of properties.

\section{Features of Nigeria's Democracy:}

- Constitutionalism: this focuses on issues of governance according to laid down rules, principles and practices.

- Periodic Elections: this idea is borrowed from Locke's philosophy on liberal democracy: It guides the processes of choosing people to govern the society.

- Separation of power: this entails a clear demarcating line between the various organs of government and their functions.

- Delineation of constituencies: this entails having defined territories for convenience of electoral practices and governance.

- $\quad$ Rule of law: this entails the supremacy of the law over other considerations in a functional system.

- Defined system of government: this according to Locke must reflect the notion of liberal democratic principles.

\section{An Assessment of Locke's idea within the context of Nigerian Democracy:}

It is worthy of note that Nigeria to a large extent is a member of treaties establishing certain rights and privileges of individuals as being superior to all other considerations in the society as elucidated by John Locke. It has all the tenets of a liberal system in theory; it is also worthy of note that Nigeria operates a democratic system modeled along the American system which scholars are of the view that it owes its origin from Locke's philosophical thoughts. One can therefore assess the Nigerian democracy as being in conformity with the ideas of liberalism emphasized in Locke's philosophical thoughts. However, this is largely in theory as what is obtainable in practice is a sharp contradiction of liberal democracy in Nigeria.

The practice of liberal democracy is still at a rudimentary stage or at its lowest ebb in Nigeria when compared with the idea in which Locke emphasizes in his philosophy and when compared to how it is practiced in advanced democracies. Not so much is considered at the level of human rights or in the dignity and worth of the human person, the processes of electing leaders are grossly flawed when compared to the idea of liberal democracy in its ideal terms. The trust in which Locke opine should rule in the interest of all in the society is viewed in the Nigerian contest as a supreme leader whose style of leadership relegates the interest of the citizenry to the background. The argument of periodic elections is grossly abused; constitutionalism is not followed in the activities of governance as there is more of impunity in the administration and governance of the system.

However, in spite of these short comings in the application of Locke's idea to Nigerian democracy, one can say with relative ease that Nigeria by virtue of being a democracy is one the right track even though pitfalls abounds

\section{Conclusion}

Locke's position and philosophical ideas has laid a path for societies to follow in the bit to attain the greatest happiness for the greatest number. His idea has equally laid the foundation for modern day liberal democratic practices that is predominant in the world today even though irregularities abounds in most underdeveloped societies like Nigeria. However, one can make reference to the American democracy which is the role model of democratic principles and practices as the best success story of John Locke's philosophical idea.

As a measure of recommendation proffered, this thesis emphasizes the entrenchment of the principles and practices of liberal democracy in the Nigerian system of government if any meaningful progress is to be made. Emphasis should be placed on the consent of individuals in policies of government, the tenets of constitution and 
constitutionalism should be held in high esteem, individual liberty and freedom should be respected, the rule of law should be held above all other considerations in the society as these to a large extent would ensure an effective system of governance.

\section{Recommendations}

The paper has recommended the following issues which may be useful for the sustenance of peace and good governance in Nigeria:

i. Governments in Nigeria should provide policies that would ensure the sustenance of peace in the society like displaying fairness, justice and equality in treating the various ethnic tribes and religious groups in the complex society like Nigeria.

ii. Government should fight issues of corruption, Unemployment, poverty election malpractice and insecurity in the country.

iii. Government should always consult the opinion of the peoples in the process of policy formulation and implementation

iv. Leadership in our political process must be a calling to serve humanity rather than a venture for self enrichment and pride.

\section{Reference}

Akindele S.T. 1987. "Synthesizing Bureaucracy and Democracy: "A Revisit" Quarterly Journal ofAdministration Vol. XX (1): Nos 1 \& 2 October 86/January 87, pp 31-56.

Akindele S.T. 1988. "The Purpose and Goals of Local Government Councils in Adebo A. et al. eds.: LocalGovernment Management System: A Practical Approach. Ibadan: Afrographika Publishing Ltd.

Armstrong SA.H (ed) 1966. Cambridge History of Later Greek and Early Medieval Philosophy, Cambridge University Press.

Boeminger, E. 1992. "Governance and Development: Issues and Constraints" in Proceedings of the WorldBank Annual Conference on DevelopmentEconomics. Washington D.C: The World Bank.Brautigam, D. 1991. Governance and Economy: A Review" World Bank Working Papers WPS 815. Chabal, P. 1992. Power in Africa, New York: St Martin'sPress.

Butler, M.A. "Early Liberal Roots of Feminism: John Locke and the Attack on Patriarchy", American Political Science Review, 72: 135-150.

Colbert, R. 1958. An Introducti10on to Western Philosophy, Princeton Publishers, London.

Creppell, Ingrid, 1996, "Locke on Toleration: The Transformation of Constraint", Political Theory, 24: 200-240.

Colman, John, 1983, John Locke's Moral Philosophy, Edinburgh: Edinburgh University Press.

Dunn, John, 1969, The Political Thought of John Locke, Cambridge: Cambridge University Press.

Erero, J., 1996. "Introduction: Return to the Source: Towards Improved Governance in Nigeria". African Journal of Institutions and Development AJID. Vol. 2, No 1 pp1-5.

Esman, M.J. 1997. "Good governance and devolution of power" in Africa Notes, May, pp 1-3.

Eyinla, B.M. 1998. "Prospects for Democracy and Good Governance in Nigeria" in Governance,Democracy and Civil Society: Conference Proceeding, Ife: Ife Social Sciences Review July.pp 70-82.

Hyden, G. 1999. "Rethinking the Study of African Politics" in D. Olowu, A. Williams andK. Soremekun (eds.). Governance and Democratization in West Africa. Senegal: Codesria.pp. 9-27.

Jega, A. 1999. "Governance and the Nigerian Economy" in Governance and the NigerianEconomy: Proceedings of the One-Day Seminar Held on January 19, 1994 first published in 1999by The Nigerian Economic Society NES. pp 101-104.

Khan, R.A. et al. 1972. Introduction to Political Science Georgetown, Ontario: Irwin Dorsey.

Olowu, D. 1995. "Transition to Democratic Governance in Africa” in D. Olowu, K.

Soremekun, A. Williams (Eds.). Governance and Democratization in Nigeria, Ibadan: Spectrum BooksLimited. pp 15-32.

Rejai, M. 1967. Democracy: The Contemporary Theories.New York. Atherton Press.

Sartori, G. 1987. The Theory of Democracy Revisited.Chatham: Chatham House Publishers.

Schumpeter J. 1955. Imperialism and Social Class. Shehu, A.Y 1999. "The Impact of Governance onMacroeconomic Management" in Governanceand the Nigerian Economy: Proceedings of the One-Day Seminar Held on January 19, 1994 firstpublished in 1999 by The Nigerian Economic

World Bank, 1989 "Sub-Sahara Africa: From Crisis toSustainable Growth: A Long-Term Perspective. 